"This is an Accepted Manuscript of an article published by Taylor \& Francis in European Education on 06 Dec 2019, available online:

http://www.tandfonline.com/10.1080/10564934.2019.1694846.” 


\title{
Collaboration between higher education institutions operating in the Czech Republic and the non-academic sphere
}

\author{
Libena Tetrevova ${ }^{\mathrm{a} *}$ and V. Vlckova ${ }^{\mathrm{b}}$ \\ ${ }^{a b}$ Department of Economy and Management of Chemical and Food Industries, \\ University of Pardubice, Pardubice, Czech Republic
}

Studentska 95, 53210 Pardubice, Czech Republic, Tel.: 00420466036661, e-mail: libena.tetrevova@upce.cz

Libena TETREVOVA is Associate Professor in Economics and Management at the University of Pardubice, the Czech Republic. She is the author of over 200 scientific and methodological works and publications. Her research interests are focused on the Triple Helix model, university social responsibility, and corporate social responsibility.

Vladimira VLCKOVA is Assistant Professor in Applied Statistics and Principles of Logistics at the University of Pardubice, the Czech Republic. She is the author of over 100 scientific and methodological works and publications. Her research interests are focused on data analysis and cooperation within the supply chain.

\section{Disclosure statement}

No potential conflict of interest was reported by the authors. 


\title{
Collaboration between higher education institutions operating in the Czech Republic and the non-academic sphere
}

\author{
The aim of the paper was to analyze and evaluate the importance, scope, and \\ applied forms of collaboration between higher education institutions (HEIs) \\ operating in the Czech Republic and the non-academic sphere. Data was obtained \\ through questionnaire survey with competent managers of HEIs $(\mathrm{N}=76)$. The \\ study shows that the managers of the monitored HEIs consider collaboration with \\ the non-academic sphere to be very important. It is perceived to be more \\ important and developed to a larger extent at the national level. Most often it is \\ developed in the form of practical training, internships, and field trips for \\ students. The considered forms of collaboration are developed most by HEIs and \\ faculties with technical, natural scientific, and medical specializations.
}

Keywords: collaboration; higher education institutions; non-academic sphere; third mission; knowledge transfer

\section{Introduction}

In today's knowledge society, the collaboration of higher education institutions (HEIs) with external entities represents an important opportunity as well as a significant factor of success for economic entities operating across all sectors of the national economy. HEIs can develop beneficial forms of collaboration with businesses, public institutions, or non-profit organizations both at the national and European level.

The key motive for this collaboration is support and transfer of knowledge (Carayannis, Barth, \& Campbell, 2012; Lugović, Šesnić, \& Sladić, 2017; Strier \& Shechter, 2016). Successfully developed collaboration is a source of sustainable economic growth and competitiveness, not only for the entities involved, but also for regions, countries and for the EU (Figus, 2015; Fongwa \& Marais, 2016; Panarina, 2015). 
Fast technological changes, the growing environmental and social demands, pressure on cuts in public expenditure and intensive global competition lead to the need for wider collaboration between HEIs and the non-academic sphere. The importance of this collaboration is highlighted at the European level by, inter alia, Communication from the Commission EUROPE 2020 - A Strategy for Smart, Sustainable and Inclusive Growth (European Commission, 2010) and Council Conclusions on a Strategic Framework for European Cooperation in Education and Training (ET 2020) (Council of the European Union, 2009).

This topic seems to be especially important from the point of view of the postcommunist countries of the EU. This is to say that significantly less R\&D expenditure (R\&D “comprise creative work undertaken on a systematic basis in order to increase the stock of knowledge, including knowledge of man, culture and society and the use of this stock of knowledge to devise new applications” (Eurostat, 2018)) is found in these countries in comparison with other EU countries. For example, R\&D expenditure of the higher education sector as a sector of performance amounted on average to EUR 136.6 per inhabitant in 2016 in the EU28. The lowest amount was registered in Bulgaria (EUR 2.7 per inhabitant). From among the post-communist countries, the highest amount was registered in Estonia (EUR 73 per inhabitant) and the Czech Republic (EUR 57.4 per inhabitant) (Eurostat, 2018).

From the point of view of post-communist countries, another key issue in view of the quality of the workforce and its employability is establishment of world-class universities. However, as is evident from the Academic Ranking of World Universities, from among the post-communist countries, only the Charles University based in the Czech Republic is included in the TOP 300 universities (ARWU, 2018).

Nevertheless, development of collaboration between HEIs and the non-academic 
sphere plays a positive role on the one hand within the framework of research, development and innovation (Anrah, 2013; Wynn \& Jones, 2017), but also within the framework of establishment of world-class universities (Franco \& Haase, 2015; Horta, 2009). This is why, from the point of view of post-communist countries, a key role must in particular be played by international collaboration, which can be a source of inspirational observations, including examples of good practice.

Despite the fact that the topic of collaboration with the non-academic sphere is becoming increasingly important over time, it is still not given sufficient attention (Boehm \& Hogan, 2013). Studies devoted to collaboration between HEIs and the nonacademic sphere which have been performed to date are subject to certain limitations.

Firstly, this concerns studies which deal only with selected specific topics, e.g. the study by Muscio (2009) was devoted to organisational provision of collaboration on the part of HEIs, the study by Klofsten \& Jones-Evans (2000) was focused on university entrepreneurial activities and the study by Sturzova (2005) assessed collaboration on the part of HEIs in the field of education.

Secondly, this concerns studies which are based on examination of a very limited data sample; e.g. the respondents in the study by Philpott, Dooley, O’Reilly, \& Lupton (2011) were 13 professors, the respondents in the study by Veteska \& Sebkova (2010), just like the study by Husarova (2007) were 19 managers of HEIs. In addition to this, several studies devoted to this topic were performed ten or more years ago, e.g. the studies by Klofsten \& Jones-Evans (2000), Husarova (2007), or Pavlin (2009).

It is thus necessary to extend the knowledge in this field to include an up-to-date and comprehensive overview of the given issue from the point of view of postcommunist countries and to thus encourage discussion of this topic. In its capacity as a post-communist economy with a traditional role played by education, which in 
comparison with other post-communist countries holds a leading position both within the framework of R\&D expenditure and also within the framework of the Academic Ranking of World Universities, the Czech Republic thus seems to be a suitable subject of research. The aim of the present study was to analyze and evaluate the importance, scope, and applied forms of collaboration between HEIs operating in the Czech Republic and the non-academic sphere.

\section{Literature review}

Research conducted in the past in the Czech Republic (e.g. Husarova, 2007; Veteska \& Sebkova, 2010) and abroad (e.g. Philpott et al., 2011; Rakovska, Pavlin, \& Melink, 2012) shows that collaboration between HEIs and the non-academic sphere is significant and beneficial. In the case of technical faculties and HEIs (Philpott et al., 2011; Veteska \& Sebkova, 2010), it is considered to be absolutely essential, and also particularly important in the case of science and health-related faculties and HEIs (Philpott et al., 2011).

The collaboration of HEIs with external subjects is developed within the socalled third mission of HEIs (Dan, 2012; Laredo, 2007; Loi \& Di Guardo, 2015). It is formed in close connection both to their first mission, which is education, and to their second mission, which refers to scientific research activities.

In connection with the first mission, such collaboration may take the form of the participation of practitioners in the preparation of the curriculum, the teaching of vocational subjects, and the creation of final papers (Kostalova \& Tetrevova, 2013; Rakovska et al., 2012; Veteska \& Sebkova, 2010). Collaboration can also be developed through field trips, practical training, and internships for students, as well as research fellowships for academics and researchers, or alternatively through the organization of 
student recruitment for external subjects (Husarova, 2007; Rakovska et al., 2012; Sturzova, 2005). An alternative form of collaboration is individually-tailored offers of training courses for external entities (Husarova, 2007; Klofsten \& Jones-Evans, 2000; Pahurkar, 2015; Philpott et al., 2011). The establishment of a corporate university can be considered the highest quality partnership in this area (Tetrevova, Vavra, Bednarikova, Munzarova, \& Kostalova, 2017).

In connection with the second mission, collaboration can take the form of the implementation of projects to order by an external subject, the joint implementation of projects, as well as the mutual use of equipment such as specialized laboratories or facilities (Barbolla \& Corredera, 2009; D’Este \& Perkmann, 2011; Husarova, 2007; Perkman et al., 2013; Philpott et al., 2011; Rakovska et al., 2012). Collaboration can also be developed in the form of jointly organized conferences and workshops (Kostalova \& Tetrevova, 2013; Rakovska et al., 2012), the mutual elaboration of expert opinion, the provision of consultations (Grimpe \& Fier, 2009; Husarova, 2007; Jessop, 2017; Klofsten \& Jones-Evans, 2000), and joint publishing activities (Grimpe \& Fier, 2009; Perkman et al., 2013; Philpott et al., 2011).

These forms of collaboration are given different emphases in different countries and receive different levels of attention. As demonstrated in a study by Pavlin (2009), in Lithuania, Hungary and Slovenia, practical training and internships are considered the most important forms of collaboration with the non-academic sphere, while in the case of Turkey, it is the organization of student recruitment in the form of career days. A study by Rakovska et al. (2012) showed that successfully applied forms of collaboration in Bulgaria, Hungary, Poland, Slovenia and Spain in the field of education included practical training and internships, collaboration in the placement of students, scholarship programmes, and collaboration in the preparation of curricula. In the area of 
scientific research, successful collaboration involved the joint implementation of projects. Another form of collaboration developed in these countries was the participation of representatives of external entities in the bodies of HEIs and faculties.

\section{Data and methodology}

The aim of the study was to analyze and evaluate the importance, scope, and applied forms of collaboration between HEIs operating in the Czech Republic and the nonacademic sphere. The above-defined aim can be narrowed down and specified by the following research questions:

1) What importance do managers of HEIs/faculties attribute to collaboration between the HEIs/faculties they manage and the non-academic sphere (business enterprises, public sector bodies, and non-profit organizations)?

2) In which scope do HEIs/faculties collaborate with the non-academic sphere from the point of view of individual types of partners?

3) What importance do managers of HEIs/faculties attribute to collaboration with domestic and foreign business enterprises, public sector bodies, and non-profit organisations?

4) Which forms of collaboration with the non-academic sphere do different types of HEIs/faculties implement?

The study is based on quantitative research. Primary data were obtained through a questionnaire survey. The reason for choice of this data collection technique was to enable us to quickly collect responses from a relatively large number of people in scattered and remote locations (Rowley, 2014), this being with the minimum costs (Brace, 2018). 
The following parts of the text analyze and evaluate data obtained from the following three questions. The first, closed question was, "How important do you consider collaboration of your HEI/faculty with the non-academic sphere (business entities, public institutions, and non-profit organizations)?" The respondents evaluated the importance of collaboration on a seven-point Likert scale.

The second, closed, question was: "Does your HEI/faculty collaborate with the entities listed below? If so, how do you assess the importance of this collaboration?" The checklist included the following entities: business entities from the Czech Republic, business entities from abroad, public institutions from the Czech Republic, public institutions from abroad, non-profit organizations from the Czech Republic, and nonprofit organizations from abroad. The respondents evaluated the importance of collaboration with the abovementioned types of partners analogously to the previous question on a seven-point Likert scale.

The third, semi-closed question was: "What forms of collaboration does your HEI/faculty develop with the non-academic sphere, i.e. with business entities, public institutions, or non-profit organizations?" The respondents could choose more than one option from the checklist and add other areas of collaboration. The checklist included the following ten possible areas of collaboration: participation in the preparation of curricula, participation in the preparation of theses, the organization of student field trips, the provision of student practical training and internships, the provision of fellowships for academics and researchers, the organization of student recruitment events, the organization of training courses, collaboration on joint projects, the sharing of expert opinion, the provision of expert consultation.

The questionnaire survey addressed representatives of all HEIs operating on that date in the Czech Republic as registered in the Ministry of Education, Youth and Sports 
of the Czech Republic database (Ministry of Education, Youth and Sports of the Czech Republic, 2015). As of June 1, 2015, there were 24 university HEIs in the Czech Republic, divided into faculties and providing all types of study programmes, and 48 non-university HEIs, not divided into faculties and providing only bachelor's and master's degree programmes. Specifically, these included 26 public HEIs (of which 22 were universities comprising 143 faculties, and 4 were non-university HEIs), 2 state HEIs (both of the university type comprising 5 faculties) and 44 private non-university HEIs. Public and state HEIs are HEIs funded mainly from public sources, namely the Ministry of Education in the case of public HEIs and the Ministry of Defence and Interior in the case of state HEIs. Private HEIs are funded primarily from private sources. In total, 196 managers of HEIs were approached.

The structure of respondents is evident from Table 1 . Specifically, there were 48 vice-rectors of non-university HEIs (44 vice-rectors of private HEIs and 4 vice-rectors of public HEIs) and 148 vice-deans of university HEIs (143 vice-deans of public universities and 5 vice-deans of state universities), whose competence included collaboration with external entities. They were vice-rectors and vice-deans for external relations, or vice-rectors and vice-deans for development.

The reasons for selecting this sample of respondents were as follows. In the case of non-university HEIs, not divided into faculties, collaboration is provided at the central level. The issue of collaboration thus falls within the competence of the respective vice-rector. In the case of university HEIs, the university is an institutional umbrella of the faculties. Collaboration with external entities is, in practice, carried out by individual faculties comprising the university, although the rectorate may act as an intermediary. The issue of collaboration thus primarily lies within the competence of the relevant vice-dean. Vice-rectors and vice-deans whose competencies are related to the 
issue of collaboration with external entities have the best information on the importance, forms, and possibilities of developing collaboration, as well as its implementation. They participate in all important negotiations on this issue, have access to strategic documents concerning collaboration with external entities, participate in the creation thereof, and, last but not least, have significant experience in implementing collaboration in practice.

The respondents were contacted through e-mail and asked to fill out an electronic form of the questionnaire in the LimeSurvey application. The return on the questionnaire survey was 39 percent (76 completed questionnaires). The relatively low response rate can be regarded as a limiting factor of the above-mentioned study. This emerged especially from the point of view of representatives of private HEIs. In an attempt to increase the response rate, the respondents were contacted personally before the questionnaire was sent and the survey was conducted in two rounds. In relation to this, it must be mentioned that a 39\% return on the questionnaire survey is aboveaverage in the current conditions of the Czech Republic. In addition, the $\chi^{2}$ goodnessof-fit tests performed at the 0.05 level of significance demonstrated the goodness of fit of the structure of the population and the sample obtained in terms of the representation of public, state and private HEIs and in terms of their specialization.

The data obtained were processed using IBM SPSS Statistics software version 24.0. Specifically, descriptive and inferential statistics were applied. Results for the whole set of respondents were first processed, then an analysis of differences was performed according to the two monitored classification attributes, i.e. according to the specializations of HEIs/faculties (HEIs/faculties were grouped into three groups by their branch affinity using the typology devised by Biglan (1973) and Kolb (1981). Group 1 comprised HEIs/faculties with a technical, scientific, or medical specialization. Group 2 
comprised HEIs/faculties of economics and law. Group 3 comprised HEIs/faculties of humanities, arts, and pedagogy.) and how the institutions are financed.

The reason why differences were analysed from the point of view of specialisations of HEIs/faculties is the fact that the approach taken by HEIs/faculties with different specialisations to collaboration with the non-academic sphere differs, as is for example stated by Ankrah \& AL-Tabbaa (2015), Philipott et al. (2011), or Veteska \& Sebkova (2010).

The reason why analysis was performed of differences from the point of view of method of financing of HEIs is that this factor has a significant impact on the approach taken by HEIs/faculties to collaboration, as is stated among others by Ankrah \& ALTabbaa (2015). In addition to this, in the conditions found in the Czech Republic, public and state HEIs are traditionally HEIs with a long history, as opposed to private HEIs which were not established until after the Velvet Revolution and which focus primarily on the first mission.

Differences in the empirical distributions of the respondents' responses were tested using the Kruskal-Wallis test and chi-square test at the 5 percent confidence level. The structural characteristics of the obtained dataset are shown in Table 2.

Table 2.

\section{Results and discussion}

\section{Importance of collaboration between HEIs/faculties and the non-academic sphere}

In the study, the importance of collaboration between HEIs/faculties and the nonacademic sphere, i.e. with business entities, public institutions and non-profit organizations, was first assessed. Competent managers of HEIs and faculties operating 
in the Czech Republic evaluated the importance of this collaboration on a seven-point Likert scale. The results are shown in Table 3.

Table 3.

The positive fact is that the managers of the HEIs and faculties who participated in the survey considered the importance of collaboration between HEIs/faculties and the non-academic sphere on average as very important, regardless of how their institutions were funded or the nature of their specialization. The Kruskal-Wallis test did not show any difference in the perception of the importance of collaboration with the nonacademic sphere between HEIs and their faculties funded mainly from public sources and those funded mostly from private sources (significance 0.265 ). No differences in the perception of the importance of collaboration with the non-academic sphere were evident even among HEIs and faculties of various fields of study (significance 0.339).

\section{Scope and importance of collaboration between HEIs/faculties and the non- academic sphere in terms of the type of partners}

The study further examined the types of partners of HEIs and faculties operating in the Czech Republic. Collaboration was assessed with entities of all key institutional sectors, excluding households, i.e. business entities, public institutions and non-profit organizations, both at the national and international level. The extent to which the HEIs and faculties in question develop collaboration with each of the above-mentioned types of subjects is evident from Table 4.

Table 4. 
It is clear from the survey that the monitored HEIs/faculties develop collaboration especially at the national level; more than half of the HEIs/faculties studied collaborate with entities from the Czech Republic. At the national level, they collaborate to the greatest extent with public institutions, then with business entities, and, to the smallest extent, with non-profit organizations. Meanwhile, less than half the HEIs/faculties studied cooperate with foreign entities. At the international level, collaboration is developed to the largest extent with foreign business entities, then with public institutions, and to the smallest extent with non-profit organizations (Table 4). These findings cannot be considered positive, either from the national or international perspective - in particular, from the international one. As a result of the given state of affairs, the knowledge potential of HEIs operating in the Czech Republic cannot be sufficiently utilised. Both the transfer of knowledge to external entities, which supports the implementation of innovation that is vital for economic growth and competitiveness (Etzkowitz, 2008; Etzkowitz, Dzisah, Ranga, \& Zhou, 2007; H. Ju, Zhang, Zhao, \& Ju, 2016), and the transfer of knowledge to the academics, scientists and students of HEIs, which is an important prerequisite for building world-class higher education institutions and engaging in globally recognized research activities (Boehm \& Hogan, 2013; D’Este \& Perkmann, 2011; Horta, 2009), are limited.

The evaluation of the importance of the collaboration of HEIs/faculties with the above-defined six types of external entities is presented in Table 5.

Table 5.

It is also clear from the survey that, in accordance with the previous findings, collaboration with individual types of entities from the Czech Republic is always considered more important than collaboration with the given types of entities from 
abroad (Table 5). Differences in the perceptions of the importance of collaboration with these types of external subjects according to how HEIs are funded and the group of disciplines they represent are shown in Table 6 and Table 7.

Table 6.

Table 7.

The results of the Kruskal-Wallis test confirmed differences in the distribution of responses only in the case of two types of partner subjects when considering the group of disciplines (Table 6 and Table 7). Collaboration with business entities from the Czech Republic was rated by the respondents of HEIs/faculties specializing in humanities, arts and pedagogy as less significant compared to the remaining two groups of specializations. Similar findings were also arrived at by Philipott et al. (2011), who documented greater emphasis placed on the business role of universities by institutions with a technical, natural scientific, medical, and economic focus. Collaboration with public institutions from the Czech Republic was rated by the respondents of HEIs/faculties of economics and law as more important when compared to other groups of disciplines, which seems logical with regard to their branch specialization.

\section{Forms of collaboration between HEIs/faculties and the non-academic sphere}

The study also investigated the forms of collaboration developed by individual HEIs/faculties with the non-academic sphere, again with a view to how these might be influenced by the method of HEI funding (Table 8) and by the HEI branch specialization (Table 9). Implemented forms of collaboration with the non-academic sphere were identified by the respondents using a list of ten potential forms of collaboration. Other forms of collaboration mentioned were exhibitions, art projects, 
product design, and the expert analysis of measurements (in all cases, the form was mentioned by only one respondent). Given their highly specific nature, these forms of collaboration were not included in further assessment.

Table 8.

Analysis of the results in Table 8 shows that the most frequently developed forms of collaboration related to student practical training and internships and student field trips, developed by more than three quarters of the HEIs/faculties studied. This finding corresponds to the results obtained by Pavlin (2009) and Rakovska et al. (2012) for other countries.

However, in the light of these two studies, the levels of the other defined forms of collaboration in the Czech Republic identified in the present study are evidently different from levels in other countries. Collaboration relating to joint projects, the preparation of thesis, training courses, consulting, and expert opinion is developed by more than half of the HEIs/faculties. Collaboration in the form of the organization of student recruitment events for external entities and participation in the preparation of curricula is developed by less than half of the respondents. The least developed form of collaboration concerns the provision of fellowships for academics and researchers.

The $\chi^{2}$ test showed that the method of HEI funding only influenced collaboration concerning fellowships for academics and researchers - that is, that private HEIs develop significantly less of this kind of collaboration ( $\chi 2$ value is 0.024$)$. The reason for this is that private HEIs operating in the Czech Republic provide education almost exclusively in the social sciences and that this form of cooperation is therefore not so readily available or beneficial for them. Moreover, due to their relatively younger age, private HEIs have fewer of the contacts required to implement this form of cooperation. 
Table 9.

It is clear from the results in Table 9 that, with two exceptions, forms of collaboration are developed most by HEIs/faculties with a technical, natural scientific, and medical focus (Group 1). The two exceptions are collaboration relating to student field trips and consulting, which are most developed by HEIs/faculties of economics and law. In contrast, all these forms of collaboration are developed least by HEIs/faculties with a humanistic, artistic and pedagogical focus (Group 3), with the only exception being collaboration in the form of joint projects.

The chi-square test at a 5 percent confidence level demonstrated that the branch specialization of HEIs/faculties influences the developed forms of collaboration more than the way they are funded. Specifically, participation in the creation of theses is developed significantly less by HEIs/faculties with a humanistic, artistic and pedagogical focus (Group 3), while fellowships for academics and researchers and the organization of student recruitment events for external entities, e.g. in the form of contact days and joint projects are developed significantly more by Group 1, i.e. HEIs and faculties with a technical, natural scientific, and medical focus.

These findings confirm previously published conclusions regarding the improvement of preconditions for the development of collaboration with the nonacademic sphere primarily from the point of view of HEIs and faculties with a technical, natural scientific and medical focus (see more Husarova (2007), Philpott et al. (2011) or Veteska \& Sebkova (2010)), and from the point of view of HEIs and faculties with an economic and business focus (see more Husarova (2007)).

\section{Conclusion}

The study shows that the managements of the surveyed HEIs and faculties operating in 
the Czech Republic are aware of the potential benefits and importance of collaboration with the non-academic sphere and consider collaboration with business, public, and third sectors to be very important. A controversial finding, however, is that collaboration with the non-academic sphere at the national level is perceived to be more important than collaboration at the international level.

As for the actual extent to which collaboration is developed in practice, it cannot be considered sufficient. While more than half of HEIs/faculties develop collaboration with the above-mentioned types of subjects at the national level, it is developed by less than half of them at the international level. This fact may be affected by several factors. Apart from the specialisation of HEIs/faculties, this could for example concern the different period of existence of HEIs/faculties, the quality of their scientific research and educational activity under international comparison, the quality of management of the HEIs and faculties and their interest in collaboration, the scope and diversity of the network of individual contacts between workers at HEIs/faculties or the geographical location of HEIs/faculties. However, in an advanced knowledge society, it is legitimate to assume that all HEIs/faculties should develop effective forms of collaboration with entities of all institutional sectors, and not only on the national level but, above all, on the international level.

Regarding particular forms of collaboration, in the context of their first mission, HEIs and faculties operating in the Czech Republic most frequently develop collaboration with the non-academic sphere in the field of education, in the form of student practical training and internships and student field trips. These forms of collaboration are developed by more than three quarters of the HEIs/faculties surveyed. In contrast, the least developed form of collaboration is the provision of fellowships for academics and researchers; this form of collaboration is developed significantly less by 
private HEIs. With only two exceptions - namely, student field trips and consulting, which are developed mainly by HEIs/faculties of economics and law - the forms of collaboration considered in this study are developed most by HEIs/faculties with a technical, natural scientific, and medical focus. These are the HEIs and faculties that traditionally have the best prerequisites for developing collaboration with the nonacademic sphere.

These findings show that the issue needs to be discussed more broadly and that more effective measures need to be taken in order to develop collaboration between HEIs and the non-academic sphere. It is necessary to develop collaboration especially at the international level. It also seems expedient to broaden the range of collaborating partners and the applied forms of collaboration, both from the point of view of public, state and, above all, private HEIs, and HEIs and faculties of all fields of study, especially those in Groups 2 and 3.

Certain measures should be taken by both the responsible national or international bodies, see more e.g. in (Council of the European Union, 2009), and the HEIs/faculties themselves, see more e.g. in (Tetrevova \& Vlckova, 2018). As far as responsible authorities are concerned, changes should be initiated both at the transnational level, i.e. by the competent EU authorities, and at the national level, i.e. by the Ministry of Education, Youth and Sports of the Czech Republic.

The present study brings a number of original findings, but at the same time poses a number of research questions suggesting directions for further research. For example, it would be useful to conduct comparative studies at the EU level. It would also seem productive to undertake a closer examination of why the extent of collaboration between HEIs and the non-academic sphere is currently rather limited. 
Studies aimed at exploring non-academic perspectives on collaboration with HEIs could also yield interesting findings.

\section{References}

Ankrah, S., \& AL-Tabbaa, O. (2015). Universities-industry collaboration: A systematic review. Scandinavian Journal of Management, 31(3), 387-408.

doi:10.1016/j.scaman.2015.02.003

Anrah, S. (2013). University-industry interorganisational relationships for technology/knowledge transfer: A systematic literature review. SSRN Electronic Journal. doi:10.2139/ssrn.2241333

ARWU. (2018). Academic Ranking of World Universities [online]. Retrieved from http://www.shanghairanking.com/ARWU2018.html

Barbolla, A. M. B., \& Corredera, J. R. C. (2009). Critical factors for success in university-industry research projects. Technology Analysis \& Strategic Management, 21(5), 599-616. doi: 10.1080/09537320902969133

Biglan, A. (1973). The characteristics of subject matter in different academic areas. Journal of Applied Psychology, 57(3), 195-203. doi: 10.1037/h0034701 Boehm, D. N., \& Hogan, T. (2013). Science-to-business collaborations: A science-tobusiness marketing perspective on scientific knowledge commercialization. Industrial Marketing Management, 42(4), 564-579. doi:10.1016/j.indmarman.2012.12.001 Brace, I. (2018). Questionnaire design: How to plan, structure and write survey material for effective market research. London: Kogan Page.

Carayannis, E. G., Barth, T. D., \& Campbell, D. F. J. (2012). The quintuple helix innovation model: Global warming as a challenge and driver for innovation. Journal of Innovation and Entrepreneurship, 1(1), 1-12. doi: 10.1186/2192-5372-1-2 
Council of the European Union (2009). Council Conclusions on a Strategic Framework for European Cooperation in Education and Training (ET 2020) [online]. Retrieved from https://www.strukturalni-fondy.cz/getmedia/06f74c37-41d4-48ea-bf75b84188a9f434/Strategicky-ramec-evropske-spoluprace-v-oblasti-vzdelavani-a-odbornepripravy-(ET-2020).pdf?ext=.pdf

D’Este, P., \& Perkmann, M. (2011). Why do academics engage with industry? The entrepreneurial university and individual motivations. The Journal of Technology Transfer, 36(3), 316-339. doi: 10.1007/s10961-010-9153-z

Dan, M. C. (2012). The third mission of universities in the development strategy of Vienna city. Informatica Economică, 16(4), 49-56.

Etzkowitz, H. (2008). The Triple Helix: university-industry-government. Innovation in action. New York: Routledge.

Etzkowitz, H., Dzisah, J., Ranga, M., \& Zhou, C. (2007). The Triple Helix model of innovation: university-industry-government interaction. Tech Monitor, 24(1), 14-23. European Commission (2010). Communication from the Commission EUROPE 2020 A Strategy for Smart, Sustainable and Inclusive Growth [online]. Retrieved from http://ec.europa.eu/eu2020/pdf/COMPLET\%20EN\%20BARROSO\%20\%20\%20007\%2 0-\%20Europe\%202020\%20-\%20EN\%20version.pdf Eurostat (2018). Science, technology and innovation [on-line]. Retrieved from http://ec.europa.eu/eurostat/web/science-technology-innovation/data/database Figus, A. (2015). Beyond Bologna: The sustainable university enterprises partnership. International Journal of Innovation and Economic Development, 2(3), 37-44. doi:10.18775/ijied.1849-7551-7020.2015.23.2005 
Fongwa, N. S., \& Marais, L. (2016). University, knowledge and regional development: Factors affecting knowledge transfer in a developing region. Africa Education Review, 13(3-4), 191-210. doi:10.1080/18146627.2016.1224587

Franco, M., \& Haase, H. (2015). University-industry cooperation: Researchers’ motivations and interaction channels. Journal of Engineering and Technology Management, 36, 41-51. doi:10.1016/j.jengtecman.2015.05.002

Grimpe, C., \& Fier, H. (2009). Informal university technology transfer: A comparison between the United States and Germany [online]. Retrieved from https://www.econstor.eu/bitstream/10419/27714/1/605024669.PDF Horta, H. (2009). Global and national prominent universities: Internationalization, competitiveness and the role of the state. Higher Education, 58(3), 387-405. doi: 10.1007/s10734-009-9201-5

Husarova, A. (2007). Analysis of university management, academicians, and representatives of firms and organizations of public and non-for-profit sectors needs in the area of cooperation. Research Report. Olomouc: DMD Agency. Jessop, B. (2017). Varieties of academic capitalism and entrepreneurial universities. Higher Education, 73(6), 853-870. doi: 10.1007/s10734-017-0120-6 Ju, H., Zhang, S., Zhao, S., \& Ju, X. (2016). Knowledge transfer capacity of universities and knowledge transfer success: evidence from university - industry collaborations in China. International Journal of Technology Management, 71(3/4), 278-300. doi:10.1504/ijtm.2016.078572

Klofsten, M., \& Jones-Evans, D. (2000). Comparing academic entrepreneurship in Europe - The case of Sweden and Ireland. Small Business Economics, 14(4), 299-309. Kolb, D. A. (1981). Learning styles and disciplinary differences. In A. W. Chickering (Ed.), The modern American college (pp. 232-255). San Francisco: Jossey-Bass. 
Kostalova, J., \& Tetrevova, L. (2013, August). Triple Helix model and partnerships of technical faculties of universities. Paper presented at the 5th International Conference on Applied Economics, Business and Development (AEBD '13), Chania.

Laredo, P. (2007). Revisiting the third mission of universities: Toward a renewed categorization of university activities? Higher Education Policy, 20(4), 441-456. doi: 10.1057/palgrave.hep.8300169

Loi, M., \& Di Guardo, M. C. (2015). The third mission of universities: An investigation of the espoused values. Science and Public Policy, 42(6), 855-870. doi:

10.1093/scipol/scv012

Lugović, S., Šesnić, F., \& Sladić, M. (2017). Knowledge transfer offices in the context of knowledge spillover theory of entrepreneurship. International Journal of Innovation and Economic Development, 3(4), 7-18. doi:10.18775/ijied.1849-7551-

7020.2015.34.2001

Ministry of Education, Youth and Sports of the Czech Republic (2015, June 1st). List of tertiary education institutions in the Czech Republic [online]. Retrieved from http://www.msmt.cz/vzdelavani/vysoke-skolstvi/prehled-vysokych-skol Muscio, A. (2009). What drives the university use of technology transfer offices? Evidence from Italy. The Journal of Technology Transfer, 35(2), 181-202. doi:10.1007/s10961-009-9121-7

Pahurkar, R. N. (2015). Creating entrepreneurs through entrepreneurial universities. Management, 5(2), 48-54.

Panarina, E. (2015). University-industry partnership as a key strategy for innovative sustainable economic growth. Journal of International Business Research and Marketing, 1(1), 25-28. doi:10.18775/jibrm.1849-8558.2015.11.3003 
Pavlin, S. (Ed.). (2009). Report on the qualitative analysis of higher education institutions and employers in five countries: Development of competencies in the world of work and education [online]. Retrieved from http://www.decowe.org/static/uploaded/htmlarea/finalreportshegesco/Qualitative_Analy sis_of_HEIs_and_Employers_in_Five_Countries.pdf

Perkmann, M., Tartari, V., McKelvey, M., Autio, E., Broström, A., D’Este, P., ... Sobrero, M. (2013). Academic engagement and commercialization: A review of the literature on university-industry relations. Research Policy, 42(2), 423-442. doi: 10.1016/j.respol.2012.09.007

Philpott, K., Dooley, L., O’Reilly, C., \& Lupton, G. (2011). The entrepreneurial university: Examining the underlying academic tensions. Technovation, 31(4), 161-170. doi: 10.1016/j.technovation.2010.12.003

Rakovska, N., Pavlin, S., \& Melink, M. (Eds.). (2012). Assessment of cooperation between higher education institutions and employers in Europe [online]. Retrieved from http://www.partners4value.lt/wp-content/uploads/2015/10/Assessment-of-cooperationbetween-higher-education-institutions-and-employers-in-Europe.pdf Rowley, J. (2014). Designing and using research questionnaires. Management Research Review, 37(3), 308-330. doi:10.1108/mrr-02-2013-0027

Strier, R., \& Shechter, D. (2016). Visualizing access: Knowledge development in university-community partnerships. Higher Education, 71(3), 343-359. doi: 10.1007/s10734-015-9907-5

Sturzova, J. (2005). Výsledky projektu o spolupráci vysokých škol s podniky [Project findings on cooperation between higher education institutions and enterprises]. Aula, 13(4), 18-25. 
Tetrevova, L., Vavra, J., Bednarikova, M., Munzarova, S., \& Kostalova, J. (2017).

Společenská odpovědnost firem společensky citlivých odvětví [Corporate Social Responsibility in Socially Sensitive Sectors]. Prague: Grada Publishing.

Tetrevova, L., \& Vlckova, V. (2018). Benefits, limitations and measures concerning the development of cooperation between higher education institutions and external entities. Tertiary Education and Management, 24(4), 377-394.

doi:10.1080/13583883.2018.1476579

Veteska, J., \& Sebkova, H. (Eds.). (2010). Spolupráce technických fakult veřejných vysokých škol s podniky [Cooperation between technical faculties of public higher education institutions and enterprises]. Prague: Educa Service.

Wynn, M., \& Jones, P. (2017). Knowledge transfer partnerships and the entrepreneurial university. Industry and Higher Education, 31(4), 267-278.

doi:10.1177/0950422217705442 
Table 1. Structural characteristics of the survey population.

\begin{tabular}{|c|c|c|c|c|c|}
\hline \multirow{2}{*}{$\begin{array}{l}\text { HEIs/faculties by } \\
\text { financing method }\end{array}$} & \multirow{2}{*}{$\begin{array}{c}\text { Absolute and relative } \\
\text { frequencies }\end{array}$} & \multicolumn{3}{|c|}{ HEIs/faculties by field of study } & \multirow{2}{*}{ Total } \\
\hline & & Group 1 & Group 2 & Group 3 & \\
\hline \multirow{4}{*}{$\begin{array}{l}\text { Funded from public } \\
\text { sources - public } \\
\text { and state HEIs }\end{array}$} & Frequency & 72 & 36 & 44 & 152 \\
\hline & $\begin{array}{l}\% \text { of public and state } \\
\text { HEIs }\end{array}$ & $47.4 \%$ & $23.7 \%$ & $28.9 \%$ & $100.0 \%$ \\
\hline & \% within the groups & $96.0 \%$ & $52.2 \%$ & $84.6 \%$ & $77.6 \%$ \\
\hline & $\%$ of the total & $36.7 \%$ & $18.4 \%$ & $22.4 \%$ & $77.6 \%$ \\
\hline \multirow{4}{*}{$\begin{array}{l}\text { Funded from private } \\
\text { sources - private }\end{array}$} & Frequency & 3 & 33 & 8 & 44 \\
\hline & $\%$ of private HEIs & $6.8 \%$ & $75.0 \%$ & $18.2 \%$ & $100.0 \%$ \\
\hline & \% within the groups & $4.0 \%$ & $47.8 \%$ & $15.4 \%$ & $22.4 \%$ \\
\hline & \% of the total & $1.5 \%$ & $16.8 \%$ & $4.1 \%$ & $22.4 \%$ \\
\hline \multirow{2}{*}{ Total } & Frequency & 75 & 69 & 52 & 196 \\
\hline & $\%$ of the total & $38.3 \%$ & $35.2 \%$ & $26.5 \%$ & $100.0 \%$ \\
\hline
\end{tabular}


Table 2. Structural characteristics of the obtained dataset.

\begin{tabular}{|c|c|c|c|c|c|}
\hline \multirow{2}{*}{$\begin{array}{l}\text { HEIs/faculties by } \\
\text { financing method }\end{array}$} & \multirow{2}{*}{$\begin{array}{c}\text { Absolute and relative } \\
\text { frequencies }\end{array}$} & \multicolumn{3}{|c|}{ HEIs/faculties by field of study } & \multirow{2}{*}{ Total } \\
\hline & & Group 1 & Group 2 & Group 3 & \\
\hline \multirow{4}{*}{$\begin{array}{l}\text { Funded from public } \\
\text { sources - public } \\
\text { and state HEIs }\end{array}$} & Frequency & 25 & 16 & 17 & 58 \\
\hline & $\begin{array}{l}\% \text { of public and state } \\
\text { HEIs }\end{array}$ & $43.1 \%$ & $27.6 \%$ & $29.3 \%$ & $100.0 \%$ \\
\hline & \% within the groups & $89.3 \%$ & $66.7 \%$ & $77.3 \%$ & $78.4 \%$ \\
\hline & $\%$ of the total & $33.8 \%$ & $21.6 \%$ & $23.0 \%$ & $78.4 \%$ \\
\hline \multirow{4}{*}{ Funded from private } & Frequency & 3 & 8 & 5 & 16 \\
\hline & $\%$ of private HEIs & $18.8 \%$ & $50.0 \%$ & $31.3 \%$ & $100.0 \%$ \\
\hline & \% within the groups & $10.7 \%$ & $33.3 \%$ & $22.7 \%$ & $21.6 \%$ \\
\hline & \% of the total & $4.1 \%$ & $10.8 \%$ & $6.8 \%$ & $21.6 \%$ \\
\hline \multirow{2}{*}{ Total } & Frequency & 28 & 24 & 22 & 74 \\
\hline & $\%$ of the total & $37.8 \%$ & $32.4 \%$ & $29.7 \%$ & $100.0 \%$ \\
\hline \multicolumn{2}{|l|}{ Missing } & \multicolumn{3}{|c|}{2} & $2.6 \%$ \\
\hline \multicolumn{2}{|l|}{ Total by HEI type } & \multicolumn{3}{|c|}{74} & $97.4 \%$ \\
\hline \multicolumn{2}{|l|}{ Total respondents } & \multicolumn{3}{|c|}{76} & $100.0 \%$ \\
\hline
\end{tabular}


Table 3. Importance of collaboration between HEIs/faculties and the non-academic sphere.

\begin{tabular}{|l|c|c|c|c|c|c|}
\hline \multirow{2}{*}{ Statistics } & \multicolumn{6}{|c|}{ HEIs/faculties } \\
\cline { 2 - 7 } & Total & Public and state & Private & Group 1 & Group 2 & Group 3 \\
\hline Mean & 6.03 & 6.05 & 5.94 & 6.03 & 6.21 & 5.82 \\
\hline Median & 6.00 & 6.00 & 6.00 & 6.00 & 6.00 & 6.00 \\
\hline Minimum & 3 & 3 & 4 & 3 & 4 & 3 \\
\hline Maximum & 7 & 7 & 7 & 7 & 7 & 7 \\
\hline Frequency & $76(74)$ & 58 & 16 & 30 & 24 & 22 \\
\hline \% of the total & 100.00 & 78.40 & 21.60 & 39.50 & 31.60 & 28.90 \\
\hline
\end{tabular}


Table 4. Scope of collaboration between HEIs/faculties and the non-academic sphere in terms of the type of partners.

\begin{tabular}{|l|c|c|c|c|c|c|}
\hline \multirow{2}{*}{ Collaboration of HEIs/faculties with } & \multicolumn{7}{|c|}{ Frequency } \\
\cline { 2 - 8 } & Yes & $\%$ & No & $\%$ & Missing & $\%$ \\
\hline Business entities from the Czech Republic & 50 & 65.8 & 12 & 15.8 & 14 & 18.4 \\
\hline Business entities from abroad & 31 & 40.8 & 26 & 34.2 & 19 & 25.0 \\
\hline Public institutions from the Czech Republic & 59 & 77.6 & 3 & 3.9 & 14 & 18.4 \\
\hline Public institutions from abroad & 24 & 31.6 & 29 & 28.2 & 23 & 30.3 \\
\hline Non-profit organizations from the Czech Rep. & 44 & 57.9 & 16 & 21.1 & 16 & 21.1 \\
\hline Non-profit organizations from abroad & 20 & 26.3 & 34 & 44.7 & 22 & 28.9 \\
\hline
\end{tabular}


Table 5. Importance of collaboration between HEIs/faculties and the non-academic sphere in terms of the type of partners.

\begin{tabular}{|l|c|c|c|c|c|c|c|}
\hline \multirow{2}{*}{ Collaboration of HEIs/faculties with } & \multicolumn{2}{|l|}{ Frequency } & \multirow{2}{*}{ Mean } & \multirow{2}{*}{ Mode } & \multicolumn{3}{l|}{ Percentiles } \\
\cline { 6 - 9 } & $\mathrm{N}$ & $\%$ & & & 25 & 50 & 75 \\
\hline Business entities from the Czech Rep. & 64 & 84.2 & 5.61 & 7 & 4.25 & 6.00 & 7.00 \\
\hline Business entities from abroad & 44 & 57.9 & 4.66 & 4 & 4.00 & 4.50 & 6.00 \\
\hline Public institutions from the Czech Rep. & 69 & 90.8 & 5.48 & 6 & 5.00 & 6.00 & 6.00 \\
\hline Public institutions from abroad & 39 & 51.3 & 4.31 & 4 & 3.00 & 4.00 & 6.00 \\
\hline Non-profit organizations from the Czech & 58 & 76.3 & 4.72 & 4 & 4.00 & 5.00 & 6.00 \\
Republic & & & & & & & \\
\hline Non-profit organizations from abroad & 34 & 44.7 & 4.21 & 4 & 3.00 & 4.00 & 6.00 \\
\hline
\end{tabular}

Note: $\mathrm{N}$ - absolute number of evaluations. 
Table 6. Importance of the collaboration of HEIs/faculties with individual types of partners according to how HEIs are funded.

\begin{tabular}{|l|c|c|c|c|c|}
\hline \multirow{2}{*}{ Collaboration of HEIs/faculties with } & \multicolumn{2}{|c|}{ Median of importance } & \multicolumn{3}{|c|}{ Kruskal-Wallis } \\
\cline { 2 - 7 } & Public and state & Private & $\chi^{2}$ & df & Sig. \\
\hline Business entities from the Czech Rep. & 6 & 6.5 & .300 & 1 & .584 \\
\hline Business entities from abroad & 5 & 5 & .206 & 1 & .650 \\
\hline Public institutions from the Czech Rep. & 6 & 5.5 & .029 & 1 & .866 \\
\hline Public institutions from abroad & 4 & 4 & .453 & 1 & .501 \\
\hline Non-profit organizations from the Czech & 5 & 4 & .821 & 1 & .365 \\
Republic & & & & & \\
\hline Non-profit organizations from abroad & 4 & 5 & .000 & 1 & .982 \\
\hline
\end{tabular}


Table 7. Importance of the collaboration of HEIs/faculties with individual types of partners according to HEI specialization.

\begin{tabular}{|l|c|c|c|c|c|c|}
\hline \multirow{2}{*}{ Collaboration of HEIs/faculties with } & \multicolumn{3}{|c|}{ Median of importance } & \multicolumn{2}{c|}{ Kruskal-Wallis } \\
& \multicolumn{3}{|c|}{ study } & \multicolumn{3}{c|}{ test } \\
\cline { 2 - 10 } & 1 & 2 & 3 & $\chi^{2}$ & df & Sig. \\
\hline Business entities from the Czech Rep. & 6 & 6 & 3 & 12.324 & 2 & .002 \\
\hline Business entities from abroad & 5 & 4.5 & 4 & 3.587 & 2 & .166 \\
\hline Public institutions from the Czech Rep. & 5 & 6 & 5 & 11.672 & 2 & .003 \\
\hline Public institutions from abroad & 4 & 4.5 & 4 & .275 & 2 & .871 \\
\hline Non-profit organizations from the Czech & 4 & 6 & 5 & 3.320 & 2 & .190 \\
Republic & & & & & & \\
\hline Non-profit organizations from abroad & 4 & 3.5 & 5 & 3.411 & 2 & .182 \\
\hline
\end{tabular}


Table 8. Forms of collaboration between HEIs/faculties and the non-academic sphere according to funding method.

\begin{tabular}{|c|c|c|c|c|c|c|}
\hline \multirow[t]{2}{*}{ Forms of Collaboration } & \multicolumn{2}{|c|}{$\begin{array}{l}\text { Public and } \\
\text { state HEIs }\end{array}$} & \multicolumn{2}{|c|}{$\begin{array}{c}\text { Private } \\
\text { HEIs }\end{array}$} & \multicolumn{2}{|c|}{ Total } \\
\hline & $\mathrm{N}$ & $\%$ & $\mathrm{~N}$ & $\%$ & $\mathrm{~N}$ & $\%$ \\
\hline Participation in the preparation of curricula & 27 & 46.6 & 6 & 37.5 & 33 & 43.4 \\
\hline Participation in the preparation of theses & 44 & 75.9 & 12 & 75.0 & 56 & 73.7 \\
\hline Student field trips & 48 & 82.8 & 15 & 93.8 & 63 & 82.9 \\
\hline Student practical training and internships & 52 & 89.7 & 15 & 93.8 & 67 & 88.6 \\
\hline Fellowships for academics and researchers & 25 & 43.1 & 2 & 12.5 & 27 & 35.5 \\
\hline Organization of student recruitment events & 31 & 53.5 & 6 & 37.5 & 37 & 48.7 \\
\hline Training courses & 42 & 72.4 & 13 & 81.5 & 55 & 72.4 \\
\hline Joint projects & 47 & 81.3 & 10 & 62.5 & 57 & 75.0 \\
\hline Providing expert opinions & 41 & 70.7 & 10 & 62.5 & 51 & 67.1 \\
\hline Consulting & 43 & 74.1 & 11 & 68.8 & 54 & 71.1 \\
\hline
\end{tabular}


Table 9. Forms of collaboration of HEIs/faculties with the non-academic sphere specifications regarding the field of study.

\begin{tabular}{|c|c|c|c|c|c|c|c|c|}
\hline \multirow{3}{*}{ Forms of Collaboration } & \multicolumn{6}{|c|}{ Groups of HEIs/faculties } & \multicolumn{2}{|c|}{$\chi^{2}$ test } \\
\hline & \multicolumn{2}{|c|}{1} & \multicolumn{2}{|c|}{2} & \multicolumn{2}{|r|}{3} & \multirow{2}{*}{$\chi^{2}$} & \multirow{2}{*}{ Sig. } \\
\hline & $\mathrm{N}$ & $\%$ & $\mathrm{~N}$ & $\%$ & $\mathrm{~N}$ & $\%$ & & \\
\hline $\begin{array}{l}\text { Participation in the preparation of } \\
\text { curricula }\end{array}$ & 16 & 57.1 & 12 & 50.0 & 5 & 22.7 & 5.457 & .065 \\
\hline $\begin{array}{l}\text { Participation in the preparation of } \\
\text { thesis }\end{array}$ & 25 & 89.3 & 21 & 87.5 & 11 & 50.0 & 10.444 & .005 \\
\hline Student field trips & 25 & 89.3 & 23 & 95.8 & 17 & 77.3 & 3.387 & .184 \\
\hline $\begin{array}{l}\text { Student practical training and } \\
\text { internships }\end{array}$ & 28 & 100.0 & 22 & 91.7 & 19 & 86.4 & .770 & .681 \\
\hline $\begin{array}{l}\text { Fellowships for academics and } \\
\text { researchers }\end{array}$ & 16 & 57.1 & 6 & 25.0 & 5 & 22.7 & 6.888 & .032 \\
\hline $\begin{array}{l}\text { Organization of student recruitment } \\
\text { events }\end{array}$ & 20 & 71.4 & 12 & 50.0 & 6 & 27.3 & 7.879 & .019 \\
\hline Training courses & 24 & 85.7 & 19 & 79.2 & 14 & 63.6 & 2.137 & .343 \\
\hline Joint projects & 28 & 100.0 & 16 & 66.7 & 15 & 68.2 & 7.052 & .029 \\
\hline Expert opinions & 21 & 75.0 & 17 & 70.8 & 15 & 68.2 & .040 & .980 \\
\hline Consulting & 21 & 75.0 & 20 & 83.3 & 15 & \begin{tabular}{|l|}
68.2 \\
\end{tabular} & 1.706 & .426 \\
\hline
\end{tabular}

